\title{
High-density genetic mapping for coffee leaf rust resistance
}

\author{
Valdir Diola • Giovani Greigh de Brito • \\ Eveline Teixeira Caixeta $\cdot$ Eunize Maciel-Zambolim • \\ Ney Sussumu Sakiyama • Marcelo Ehlers Loureiro
}

Received: 28 September 2010 /Revised: 21 April 2011 / Accepted: 23 May 2011

(C) Springer-Verlag 2011

\begin{abstract}
Coffee leaf rust caused by the fungus Hemileia vastatrix causes considerable economic losses for coffee producers. Although agrochemical products can provide sufficient disease control, the use of resistant cultivars is a safer alternative. This resistance may be constrained by one or a few genetic factors, mainly those found in material originating from interspecific hybrids. In this study, the genetic analysis of an $F_{2}$ population consisting of 224 plants derived from a crossing of Híbrido de Timor UFV 427-15 (resistant) with Catuaí Amarelo IAC 30 (susceptible) showed that a dominant gene confers the resistance of coffee to race II of $H$. vastatrix. From a genetic map saturated with 25 amplified fragment length polymorphism (AFLP)
\end{abstract}

\author{
Communicated by A. Abbott \\ V. Diola \\ Departamento de Genética, \\ Universidade Federal Rural do Rio de Janeiro, \\ Seropédica, Rio de Janeiro, Brazil \\ e-mail: valdirdiola@ufrrj.br \\ M. E. Loureiro $(\bowtie)$ \\ Departamento de Biologia Vegetal, \\ Universidade Federal de Viçosa, \\ Viçosa, Minas Gerias, Brazil \\ e-mail: mehlers@ufv.br \\ G. G. de Brito \\ EMBRAPA Algodão, Núcleo Cerrado, \\ Goiânia, Goiás, Brazil \\ E. T. Caixeta \\ EMBRAPA Café/Bioagro, \\ Brasilia, Distrito Federal, Brazil \\ E. Maciel-Zambolim • N. S. Sakiyama \\ BIOCAFÉ/BIOAGRO, Universidade Federal de Viçosa, \\ Viçosa, Minas Gerais, Brazil
}

markers linked to the resistance gene, we developed a high-density genetic map with six sequence-characterized amplified region (SCAR) markers delimiting a chromosomal region of $9.45 \mathrm{cM}$ and flanking the dominant gene at 0.7 and $0.9 \mathrm{cM}$. This is the first saturated and high-density genetic map obtained from this region containing the resistance gene. The results of this study are of great importance for the introduction of molecular markers for marker-assisted selection; they will also facilitate studies related to the cloning, structure, and function of race-specific genes involved in the resistance of coffee trees to $H$. vastatrix.

Keywords Coffea arabica $\cdot$ Hemileia vastatrix . Dominant resistance gene $\cdot$ High-density genetic map

\section{Introduction}

Coffee leaf rust caused by the biotrophic fungus Hemileia vastatrix is a major disease that causes great economic losses for coffee growers. The damage is mainly evidenced by a reduction in crop yield (Guzzo et al. 2009). The resistance of coffee trees to $H$. vastatrix has been explored by conventional breeding methods. Although there are known sources of monogenic, oligogenic, and polygenic resistance (Alvarado 2005), the genes that participate in the resistance mechanism at the molecular level have not yet been identified. Coffee rust resistance is conferred, either independently or jointly, by the genes $S_{H} 1, S_{H} 2, S_{H} 3, S_{H} 4$, $S_{H} 5, S_{H} 6, S_{H} 7, S_{H} 8$, and $S_{H} 9$, which may be supplanted in whole or in part by the virulence genes of the pathogen $v 1$, $v 2, v 3, v 4, v 5, v 6, v 7, v 8$, and $v 9$ (Bettencourt and Rodrigues 1988). The genes $S_{H} 1, S_{H} 2, S_{H} 4$, and $S_{H} 5$ were identified in Coffea arabica (Bettencourt and NoronhaWagner 1971), whereas genes $S_{H} 6, S_{H} 7, S_{H} 8$, and $S_{H} 9$ were 
identified in Coffea canephora (Bettencourt and Rodrigues 1988). The genes $S_{H} 6, S_{H} 7, S_{H} 8$, and $S_{H} 9$ were introgressed from $C$. canephora (Rodrigues et al. 1975) and $S_{H} 3$ from Coffea liberica (Prakash et al. 2004). Several research groups in different regions of the world have attempted to obtain durable resistance to coffee rust. However, pathogen modifications and the emergence of new races of the pathogen, as well as the occurrence of complex races, illustrate the evolutionary potential of the $H$. vastatrix population and its consequent adaptation to resistance (Cabral et al. 2009). The variability of the biotrophic fungi, including H. vastatrix, is usually high. So far, about 45 physiologic races of $H$. vastatrix have been identified from samples collected in different coffee-producing countries (Varzea and Marques 2005); 15 of these have been found in Brazil. Among these, race II, which has the virulence gene $v 5$, predominates in commercial farming areas (Fernandes et al. 2009). The majorities of commercial cultivars planted in coffee-producing regions worldwide have the $S_{H} 5$ factor and are therefore susceptible to race II of $H$. vastatrix (Fazuoli et al. 2005). The main source of genes for resistance to all races of $H$. vastatrix is currently the Híbrido de Timor (HT), a plant derived from a spontaneous crossing of $C$. arabica and C. canephora (Varzea and Marques 2005). In preliminary studies conducted by Caixeta et al. (2003) and Brito et al. (2010), it was reported that the source of resistance to race II of $H$. vastatrix can be found in plants derived from the Híbrido de Timor. In these studies, it was demonstrated that resistance in the source strain, HT UFV $427-15$, is determined by a single, still unknown resistance factor. Brito et al. (2010) suggested that this resistance gene is most likely related to one of the $\mathrm{S}_{\mathrm{H}}$ genes $\left(S_{H} 7, S_{H} 8\right.$, or $\left.S_{H} 9\right)$ that were previously identified in a Hibrido de Timor derivative or another unknown gene. In a molecular study, Brito et al. (2010) analyzed a population derived from the HT UFV 427-15 and identified three amplified fragment length polymorphism (AFLP) markers linked to the presence of the resistance gene in coffee trees.

Studying other gene, Prakash et al. (2004) screened 80 AFLP primer combinations and identified 21 AFLP markers linked to the $S_{H} 3$ gene. The $S_{H} 3$ locus is derived from introgression of $C$. liberica into $C$. arabica. Mahé et al. (2008), who identified sequence-characterized amplified region (SCAR) and SSR markers cosegregating with the gene, studied this same locus.

The number of known markers and molecular information on coffee leaf rust-resistance genes are limited (Herrera et al. 2009). To date, genetic maps saturated for C. arabica containing genes or QTLs controlling this trait have not been made available. Obtaining these maps is of paramount importance for guiding assisted selection in breeding programs as well as providing strategic tools for positional cloning of genes. Saturated genetic maps can generate secondary maps, allowing for the analysis of specific regions of the chromosome. These high-density genetic maps have been widely used to facilitate the cloning of specific genes, especially when there is little information about the genome under study.

This study aimed at mapping the chromosomal region of the coffee Híbrido de Timor UFV 427-15 around the locus that confers resistance to race II of $H$. vastatrix. We obtained a high-density map with SCAR markers derived from AFLP markers located in the region containing the resistance gene.

\section{Materials and methods}

\section{Genetic material}

We used a segregating population of 224 plants of the $F_{2}$ generation originating from a controlled self-fertilization of the F1 UFV 421-4 plant, a hybrid derived from an artificial crossing between the susceptible parental Catuaí Amarelo IAC 30 (UFV 2143-236) and the resistant HT UFV 427-15. The HT UFV 427-15 coffee tree, originating from the seeds of trees selected for rust resistance in the Regional Station of Uige of the Institute of Coffee in Angola, was brought to Brazil from the Research Center of Coffee Rust in Portugal, and it is part of the germplasm bank of UFV-EPAMIG.

The strain of $H$. vastatrix race II selected for this study was biologically characterized by Cardoso (1986), and it has since been maintained in the Laboratory of Coffee Biotechnology, Universidade Federal de Viçosa, Minas Gerais, Brazil, by periodic inoculation of cv. Catuaí seedlings kept isolated and under controlled conditions.

\section{Inoculation and disease assessment}

From each plant of the $F_{2}$ population, and from each parent plant, we collected fully expanded young leaves at full physiological activity. Leaf discs of $2.5 \mathrm{~cm}$ in diameter were obtained and stored in Gerbox ${ }^{\circledR}$ containers with the abaxial surface facing up. Two replicates of eight discs each were taken and kept in separate containers, with samples of two plants in each Gerbox ${ }^{\circledR}$ (Fig. 1). The inoculation was done by applying 10 drops of $\sim 5.0 \mu \mathrm{L}$ each of a suspension of urediniospores $\left(2.0 \mathrm{mg} \mathrm{mL}^{-1}\right)$ in distilled water to each leaf disc. The discs were then kept for $24 \mathrm{~h}$ in the dark and then transferred to a growth chamber at a temperature of $22^{\circ} \mathrm{C}$ and a photoperiod of $12 \mathrm{~h}$ (Capucho et al. 2009). Evaluations were performed at 18,24, 36, and 48 days after inoculation. The plants were classified as resistant or susceptible based on the absence or presence of pathogen urediniospores, respectively. The phenotypic segregation was determined with the "MapDisto" Version 1.7 beta software (Lorieux 2007) using the $\chi^{2}$ statistic. 
Fig. 1 Phenotypic characterization of resistance to coffee rust. a Assembly of a replica of the phenotyping test with eight leaf discs for the resistant genotype (left) and eight leaf discs of the susceptible genotype (right) 24 days after inoculation.

The presence of spores indicates that the fungus completed its life cycle and there was a compatible plant/pathogen interaction. b Close-up of the contrasting genotypes

\section{a}

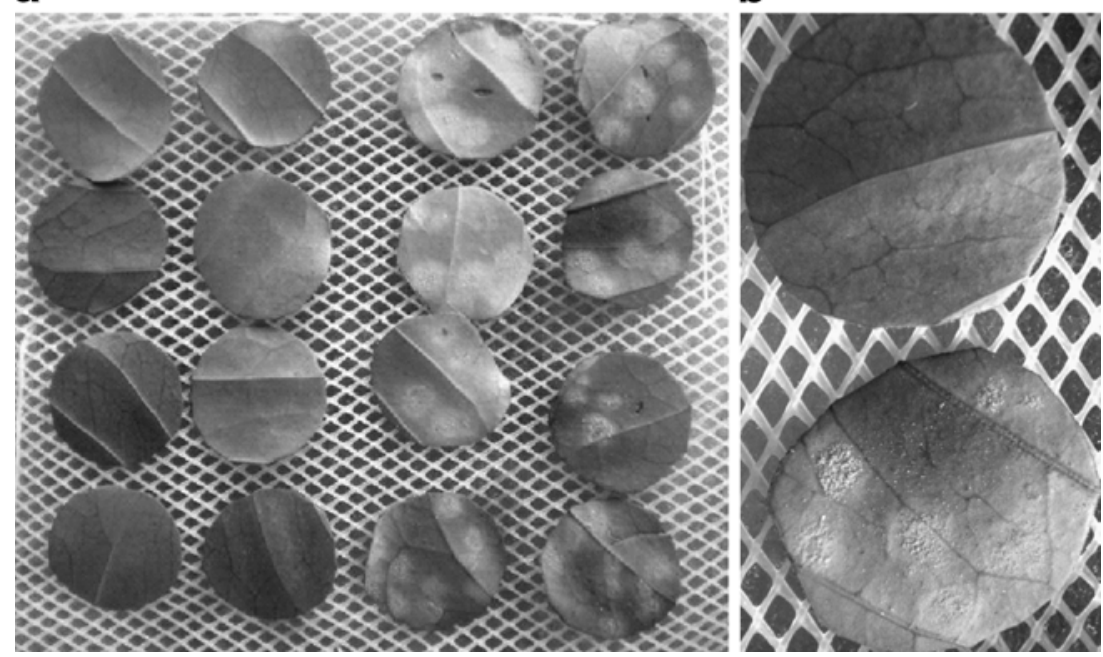

Determination of molecular AFLP markers

The extraction of genomic DNA was done according to the CTAB method (Keb-Llanes et al. 2002; Brito et al. 2010). The DNA samples were quantified with a spectrophotometer and then diluted to a concentration of $100 \mathrm{ng} \mu \mathrm{L}^{-1}$ for use; DNA quality was assessed by electrophoresis on a $1 \%$ agarose gel.

The determination of AFLP markers was performed according to the methodology proposed by Vos et al. (1995) and adapted by Brito et al. (2010). Approximately $600 \mathrm{ng}$ of DNA from each plant was digested with the restriction enzymes EcoRI (few digestion sites) and/or MseI (frequent digestion sites) according to the manufacturer's directions (Promega). Digestion proceeded for $8 \mathrm{~h}$ at $37^{\circ} \mathrm{C}$; we then performed gel electrophoresis ( $1 \%$ agarose) using about $200 \mathrm{ng}$ of DNA to evaluate the efficiency of the digestion. Ligation reactions with the adapters $d s E c o R I 5^{\prime}$-CTAGTA GACTGCGTACC-3' and dsMseI 5'-GACGATGAGTCCT GAGT-3' were performed with $400 \mathrm{ng}$ of digested DNA, $75 \mathrm{ng}$ of each adapter, $1 \mathrm{U}$ of T4 DNA ligase (Biosystem) and $1 \times$ ligase buffer in a total volume of $20 \mu \mathrm{L}$. The ligation reaction was held overnight at $8^{\circ} \mathrm{C}$. The reactions were diluted in TE buffer $(1 \times)$ at a ratio of 1:10 and stored at $-20^{\circ} \mathrm{C}$ until use.

A pre-selective amplification was performed using $75 \mathrm{ng}$ of the primers EcoRI 5'-GACTGCGTACCAATTCN-3' and/ or MseI 5'-GATGAGTCCTGAGTAAN-3' depending on the enzymes used for digestion. To a final volume of $25 \mu \mathrm{L}$, the following reagents were added: $2.5 \mu \mathrm{L}$ of the diluted digestion reaction, $1 \times$ Taq DNA polymerase buffer, $1.25 \mathrm{mM} \mathrm{MgCl}_{2}, 0.25 \mathrm{mM}$ of each dNTP (Promega), and 1.5 U Taq DNA polymerase (Phoneutria, Brazil). The amplification included 24 cycles: $94^{\circ} \mathrm{C}$ for $30 \mathrm{~s}, 58^{\circ} \mathrm{C}$ for $60 \mathrm{~s}$, and $72^{\circ} \mathrm{C}$ for $60 \mathrm{~s}$. Finally, the reaction product was diluted 40 -fold in TE (pH 8.0) and stored at $-20^{\circ} \mathrm{C}$.
In the selective amplification, we used primers containing three nucleotides added randomly to the $3^{\prime}$ end. The selective amplification was performed in a volume of $20 \mu \mathrm{L}$. We used $4.0 \mu \mathrm{L}$ of the pre-amplification reaction diluted 40 -fold and added $1 \times$ Taq DNA polymerase buffer, $1.25 \mathrm{mM} \mathrm{MgCl} 2,0.25 \mathrm{mM}$ of each dNTP (Promega), $50 \mathrm{ng}$ of each selective primer (Bioneer), and 1.5 U Taq DNA polymerase (Phoneutria). We used a touchdown PCR with 13 cycles: $94^{\circ} \mathrm{C}$ for $30 \mathrm{~s}, 65^{\circ} \mathrm{C}\left(-0.7^{\circ} \mathrm{C}\right.$ per cycle) for $30 \mathrm{~s}$, and $72^{\circ} \mathrm{C}$ for $60 \mathrm{~s}$, followed by 26 cycles of $94^{\circ} \mathrm{C}$ for $30 \mathrm{~s}, 58^{\circ} \mathrm{C}$ for $30 \mathrm{~s}$, and $72^{\circ} \mathrm{C}$ for $60 \mathrm{~s}$.

To identify AFLP markers linked to the gene for resistance to $H$. vastatrix, we used the method of bulked segregant analysis, proposed by Michelmore et al. (1991), in which each bulk, susceptible and resistant, was composed of five genotypes each (Brito et al. 2010).

The fragments of the amplified DNA were separated by electrophoresis on a denaturing $6 \%$ polyacrylamide gel $(19: 1)$ at $2,000 \mathrm{~V}$ for $2.5 \mathrm{~h}$. The gels were stained with silver nitrate as proposed by Creste et al. (2001) and adapted by Brito et al. (2010). After drying, the gel was digitally imaged to conduct the DNA polymorphism analysis.

\section{Ligation analysis}

The polymorphism analysis was performed visually and confirmed by digital densitometry using the $\mathrm{Mcdi}^{\mathrm{TM}} \mathrm{Gel} \&$ Blot Analysis System software (http://www.mcid.com.uk) by considering the absence or presence of bands. The polymorphic combination of primers, which amplified fragments in the resistant parent and the resistant pool but not in the susceptible parent and susceptible pool, was analyzed individually for each genotype constituting the bulk. The primers that confirmed bands in all resistant genotypes and not in the susceptible genotypes were analyzed across the mapping population to determine the 
genetic distances between marker and gene. The Mendelian segregation of markers in the $F_{2}$ population was tested by $\chi^{2}$ analysis at $5 \%$ probability applying the Bonferroni correction using the "MapDisto" Version 1.7 beta software (http://mapdisto.free.fr; Lorieux 2007). The same program was used to analyze the connection of heteromorphic bands with the resistance gene, assuming a maximum rate of recombination between the marker and gene of $30 \%\left(r_{\max } 0.3\right)$ and a minimum LOD score of $5.0\left(\mathrm{LOD}_{\min } 5\right)$. The recombination frequencies were converted into centiMorgan distances (cM) and a Haldane mapping function using the sum of adjacent recombination fractions criterion with the data standardized by LODs.

\section{Conversion of AFLP markers into SCAR markers}

The AFLP markers positioned less than $10 \mathrm{cM}$ from each side of the resistance gene were transformed into SCARs. The recovery of the polymorphic DNA fragment from the polyacrylamide gel was performed using the method proposed by Sambrook and Russell (2006) with some modifications. The DNA fragments of the parent and bulk resistant individuals were cut from the gel and rehydrated in $30 \mu \mathrm{L}$ of $1 \times \mathrm{TE}$ buffer and later removed from the plate through scraping. The fragments were placed in $600-\mu \mathrm{L}$ tubes and macerated in $40 \mu \mathrm{L}$ of $1 \times$ TE buffer. We collected $5 \mu \mathrm{L}$ of this solution and performed PCR in a volume of $50 \mu \mathrm{L}$ with reaction conditions similar to those of the AFLP amplification. Amplification occurred in 35 cycles: $94^{\circ} \mathrm{C}$ for $30 \mathrm{~s}, 58^{\circ} \mathrm{C}$ for $30 \mathrm{~s}$, and $72^{\circ} \mathrm{C}$ for $60 \mathrm{~s}$. The PCR product was loaded onto a $1 \%$ agarose gel and subjected to electrophoresis at $70 \mathrm{~V}$ for $30 \mathrm{~min}$. The band was extracted from the gel and purified with the Illustra GFX ${ }^{\mathrm{TM}}$ PCR DNA and Gel-Band Purification Kit (GE Healthcare, USA) according to the recommendations of the manufacturer. After DNA quantification, we used 16 ng of purified DNA fragment to conduct a ligation into the pGEM' $^{\circledR}{ }^{\circledR}$ plasmid (Promega), following the manufacturer's recommendations. The cells were transformed by heat shock (Sambrook and Russell 2006), and plasmid extraction was performed by means of alkaline lysis (Clemson and Kelly 2003). The sequencing was performed in a MegaBACE Prism 377.1000 sequencer (Amersham Biosciences).

The SCAR primer pairs were designed using the Primer Blast software (http://www.ncbi.nlm.nih.gov/tools/primer-blast). We performed amplification by PCR of the amplicons corresponding to SCAR markers on the parents and pools, followed by amplification in the mapping population. The amplification was performed in a volume of $20 \mu \mathrm{L}$ with $200 \mathrm{ng}$ of DNA sample, $1 \times$ Taq DNA polymerase buffer, $1.25 \mathrm{mM} \mathrm{MgCl}_{2}, 0.25 \mathrm{mM}$ of each dNTP (Promega), $50 \mathrm{ng}$ of each SCAR primer (Bioneer), and 1.5 U Taq DNA polymerase (Phoneutria). The PCR was performed with a multiplex set of primers in 35 cycles: $94^{\circ} \mathrm{C}$ for $30 \mathrm{~s}, 58^{\circ} \mathrm{C}$ for $30 \mathrm{~s}$, and $72^{\circ} \mathrm{C}$ for $60 \mathrm{~s}$. The samples were separated on a denaturing $6 \%$ polyacrylamide gel (19:1) and visualized by the silver nitrate method; the subsequent analytic procedures were the same as for the AFLPs.

\section{Results}

Identification and mapping of AFLP markers linked to rust resistance

To confirm the inheritance of the resistance of the Híbrido de Timor UFV 427-15, the parents and plants of the mapping population were characterized phenotypically (Fig. 1), with the identification of 166 resistant (74.1\%) and 58 susceptible plants $(25.9 \%)$. These data confirmed the 3:1 segregation pattern expected for a single, dominant gene $\left(\chi^{2}=0.09524\right.$, with a probability of $\left.75.76 \%\right)$.

Genotyping consisted of the analysis of 1,154 selective primer combinations of AFLPs, allowing for the analysis of 80,383 loci (Table 1). The number of fragments amplified by combination of primers ranged from 22 to 164, with an average of 70 fragments. Polymorphisms were observed in $77.88 \%$ of primer combinations, and the average size of the polymorphic fragments was approximately $480 \mathrm{bp}$ (data not shown).

We identified 2,138 polymorphic loci, of which 501 showed polymorphism between two parents and the two contrasting bulks. Among these, 363 loci were present in both the parent and the resistant bulk (Table 1). After analysis of 273 of these loci in the resistant and susceptible genotypes constituting the bulk (Fig. 2), we identified 25 potential markers. These were tested in the 224 genotypes of the $F_{2}$ segregating population, confirming the binding of the marker to the gene for resistance to coffee leaf rust (Table 2). From these data, the genetic map of the region containing the $R$ gene coding for resistance to $H$. vastatrix race II was saturated with the 25 AFLP markers. The map represents a chromosomal region of about $137.39 \mathrm{cM}$ (Fig. 4a).

The 25 markers underwent segregation analysis in the population. Only the ETTA-EGTA 230 marker showed segregation distortion $(p<0.05)$, that is, it showed a segregation different from the 3:1 ratio (three bands present to one missing band) expected for dominant markers. However, this marker showed an LOD score of approximately 14 , which allowed its inclusion in the linkage group (Table 2).

The markers and the resistance gene were mapped using the "Kosambi" measurements of genetic distance in a simple locus analysis. We obtained markers flanking the resistance gene at $2.0 \mathrm{cM}$ on either side: the ETCA-EATG $\mathrm{E}_{560}$ 
Table 1 Analysis of AFLP primers in the $F_{2}$ population generated by crossing the source of resistance to coffee leaf rust, Híbrido de Timor UFV 427-15, and the susceptible variety Catuaí Amarelo IAC 30

\begin{tabular}{|c|c|c|c|c|c|c|c|c|}
\hline & \multicolumn{7}{|c|}{ Combination of $\mathrm{AFLP}^{\mathrm{a}}$ primers } & \multirow{3}{*}{ Total } \\
\hline & $\mathrm{EANN} /$ & $\mathrm{EG} N N /$ & $\mathrm{ET} N N /$ & $\mathrm{ETNN} /$ & $\mathrm{ECNN} /$ & $\mathrm{ECNN/}$ & EGNN/ & \\
\hline & MTNN & MTNN & EGNN & EANN & $\operatorname{MTNN}$ & $\mathrm{MANN}$ & MGNN & \\
\hline $\begin{array}{l}\text { Number of combinations } \\
\text { analyzed }\end{array}$ & 256 & 243 & 256 & 256 & $33^{\mathrm{b}}$ & 48 & 64 & 1,154 \\
\hline Number of loci analyzed & 21,044 & 18,682 & 13,162 & 15,797 & 2,141 & 4,066 & 5,491 & 80,383 \\
\hline Polymorphic loci & 188 & 409 & 596 & 606 & 18 & 149 & 172 & 2,138 \\
\hline $\begin{array}{l}\text { Fragments in parent } \\
\text { and bulk } \mathrm{R}^{\mathrm{c}}\end{array}$ & 21 & 16 & 184 & 103 & 16 & 15 & 8 & 363 \\
\hline $\begin{array}{l}\text { Fragments in parent } \\
\text { and bulk } S^{\text {d }}\end{array}$ & 23 & 25 & 47 & 25 & 5 & 6 & 7 & 138 \\
\hline Identified markers ${ }^{\mathrm{e}}$ & 0 & 0 & 12 & 7 & 6 & 0 & 0 & 25 \\
\hline
\end{tabular}

${ }^{\mathrm{a}} \mathrm{E}$ or $\mathrm{M}$ - initials of the type of adapter used for restriction enzymes, E for EcoRI and M for MseI. A, T, C, or G-first base added to the preselected oligonucleotide adapter. $N$ refers to each additional nucleotide present in the oligos

${ }^{\mathrm{b}}$ These five combinations were previously selected because they contain polymorphisms (Brito et al. 2010)

${ }^{\mathrm{c}}$ Presence of a band only in resistant parent and bulk, which represents a potential marker linked to coupling with the resistance gene

${ }^{\mathrm{d}}$ Presence of band only in susceptible parent and bulk, which corresponds to a potential marker linked to repulsion with the resistance gene

${ }^{\mathrm{e}}$ Markers identified after individual analysis of the DNA samples from plants constituting the bulks

and ETCA-EAGA 530 markers (Fig. 4a). We selected six markers that were closely linked to the resistance gene, three on each side, that were placed at a distance less than $10 \mathrm{cM}$ from the gene. These markers were transformed into SCARs.

\section{Mapping of SCAR markers}

The selected markers were cloned and sequenced. Then, by means of the Primer-Blast program (www.ncbi.nlm.nih.gov/ tools/primer-blast/index.cgi), we obtained the respective primers (Table 3). The validation of SCAR primers was initially performed on the parents and on the genotypes of the susceptible and resistant bulks (Fig. 3) and then in the $F_{2}$ population. The mapping algorithms used were the same as those used for the AFLP markers (Table 3). The SCAR markers showed the same order and allowed us to obtain a high-density genetic map (Fig. 4b).

When compared with the AFLPs, the six SCAR markers reduced the genetic distances from 20.78 to $9.45 \mathrm{cM}$ (Fig. 4). This reduction in distance was due to the fact that the primers for the AFLP markers did not amplify the DNA sequences of some resistant coffee trees that were amplified

Fig. 2 Polymorphism of coffee rust-resistant and -susceptible individuals using a combination of AFLP ETCA-EATG primers (560 bp). a Fragments amplified only in resistant parent and resistant bulk. b Fragments present in the resistant parent and in all resistant individuals constituting the bulk, and absent in susceptible plants

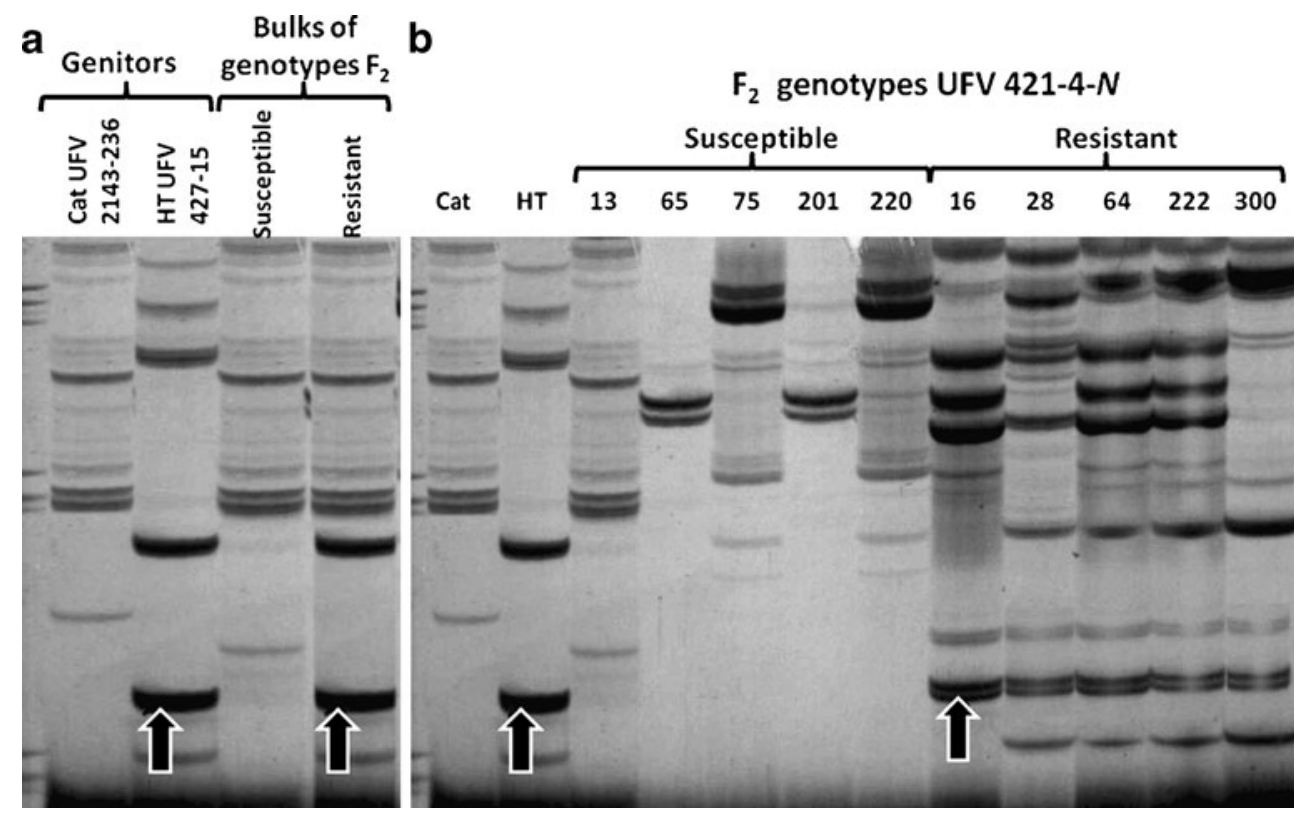


Table 2 AFLP markers linked to the gene for resistance to coffee rust present in the $F_{2}$ UFV $421-4$ population

\begin{tabular}{|c|c|c|c|c|c|}
\hline \multirow[t]{2}{*}{$\mathrm{AFLP}^{\mathrm{a}}$ marker } & \multicolumn{2}{|c|}{ Genotyping $^{\mathrm{b}}$} & \multirow{2}{*}{$\begin{array}{l}\text { Ratio } \\
\pm\end{array}$} & \multirow[t]{2}{*}{$\chi^{2 \mathrm{c}}$} & \multirow[t]{2}{*}{$p(\%)$} \\
\hline & - & + & & & \\
\hline Phenotype & 58 & 166 & 2.86 & 0.095 & 75.76 \\
\hline EGTA-ETGA $_{605}$ & 58 & 166 & 2.86 & 0.095 & 75.76 \\
\hline ECTC-MTTT $_{280}$ & 53 & 171 & 3.23 & 0.214 & 64.34 \\
\hline ECCT-MTTC $_{300}$ & 46 & 178 & 3.87 & 2.381 & 12.28 \\
\hline ECGT-MTGT $_{280}$ & 48 & 176 & 3.67 & 1.524 & 21.70 \\
\hline ECGT-MTGT $_{210}$ & 54 & 170 & 3.15 & 0.095 & 75.76 \\
\hline ECAT-MTCT $_{150}$ & 57 & 167 & 2.93 & 0.024 & 87.74 \\
\hline ECAT-MTCT $_{130}$ & 61 & 163 & 2.67 & 0.595 & 44.04 \\
\hline ETGA-EGCA $_{310}$ & 46 & 178 & 3.87 & 2.381 & 12.22 \\
\hline ETGA-EGCA $_{280}$ & 51 & 173 & 3.39 & 0.595 & 44.04 \\
\hline ETAT-EGGC $_{480}$ & 57 & 167 & 2.93 & 0.024 & 87.74 \\
\hline ETAT-EGGC $_{380}$ & 53 & 171 & 3.23 & 0.214 & 64.34 \\
\hline ETAT-EGTT $_{385}$ & 60 & 164 & 2.73 & 0.381 & 53.71 \\
\hline ETTC-EGAG ${ }_{450}$ & 48 & 176 & 3.67 & 1.524 & 21.70 \\
\hline ETTA-EGTA $_{650}$ & 47 & 177 & 3.77 & 1.929 & 16.49 \\
\hline ETTA-EGTA $_{230}$ & 41 & 183 & 4.46 & 5.357 & 2.06 \\
\hline ETCA-EGTA $_{480}$ & 58 & 166 & 2.86 & 0.095 & 75.76 \\
\hline ETTC-EGAT $_{230}$ & 46 & 178 & 3.87 & 2.381 & 12.22 \\
\hline ETGT-EGGG $_{350}$ & 51 & 173 & 3.39 & 0.595 & 44.04 \\
\hline ETCA-EATG $_{560}$ & 51 & 173 & 3.39 & 0.595 & 44.04 \\
\hline ETCA-EAGA $_{530}$ & 55 & 169 & 3.07 & 0.024 & 87.74 \\
\hline ETCT-EAGA $_{480}$ & 48 & 176 & 3.67 & 1.524 & 21.70 \\
\hline ETCT-EATT $_{420}$ & 47 & 177 & 3.77 & 1.929 & 16.49 \\
\hline ETGT-EACA $_{480}$ & 57 & 167 & 2.93 & 0.024 & 87.74 \\
\hline ETGC-EACA ${ }_{530}$ & 57 & 167 & 2.93 & 0.024 & 87.74 \\
\hline ETGT-EACA $_{380}$ & 60 & 164 & 2.73 & 0.381 & 53.71 \\
\hline
\end{tabular}

${ }^{\mathrm{a}}$ Combination of primers. $\mathrm{E}$ or $\mathrm{M}$ - initials of the restriction enzyme ( $\mathrm{E}=\mathrm{EcoRI}$ or $\mathrm{M}=\mathrm{MseI}$ ) followed by three additional bases to the adapter; subscripts indicate the estimated sizes of the fragments by comparison with the molecular weight marker

${ }^{\mathrm{b}}$ The (-) sign indicates no amplicon and $(+)$ indicates the presence of an amplicon in individuals from the mapping population

${ }^{\mathrm{c}}$ Chi-square test with one degree of freedom (dominant monogenic inheritance: 3 R_(+)/1 $\mathrm{rr}(-)), \alpha=0.05$ level of probability

as their respective SCAR primers. As observed in Table 4, except for the CaRHvII $6_{437}$ marker, the SCARs were amplified from all the resistant genotypes. In addition, the amplification of susceptible genotypes was reduced by $21.3 \%$ when SCARs were used (from 47 with AFLP to 37 with SCAR; Table 4), contributing to the reduction in genetic distances. The resistance gene, flanked by AFLP markers at $4.0 \mathrm{cM}$, was positioned within a region of $1.6 \mathrm{cM}$ delimited by the SCAR CaRHv $1_{533}$ (derived from the ETCA-ETAG 560 marker) and CaHvII $3_{459}$ (derived from ETCA-EAGA ${ }_{320}$ ) markers (Fig. 4b). Thus, these SCAR markers cosegregate with the resistance gene in this population and therefore constitute essential tools for their application in marker-assisted selection (MAS) to increase selection efficiency.

\section{Discussion}

The inoculations of mapping population plants $\left(F_{2}\right)$ with race II of $H$. vastatrix allowed for the phenotypic and genotypic confirmation of the monogenic dominant inheritance of the resistance of Híbrido de Timor UFV 427-15. However, this result does not exclude the possibility that the locus under study corresponds to a complex grouping of several resistance genes arranged in tandem and segregated as a single locus, as reported for other species of plants (Town et al. 2006).

Beginning with the work of Brito et al. (2010), considerable progress has been made toward the saturation of the genetic map and the identification of markers that cosegregate with the locus for resistance to the pathotype of race II of $H$. vastatrix, encoded by an as-yet unidentified gene (or genes). This result is similar to those obtained by the researchers studying the $S_{H} 3$ locus; it is similarly possible that more than one gene may be included in the MAS.

For the molecular analysis, we used 1,154 primer combinations, which generated 83,383 loci. This enabled the identification of 25 molecular markers linked to the resistance gene. The information found was consistent with the results obtained by Brito et al. (2010), who found three markers using 176 AFLP primer combinations. However, the number of markers obtained was significantly lower than that found by Prakash et al. (2004). These authors selected 80 primer combinations and identified 21 AFLP markers linked to the $S_{H} 3$ gene. This discrepancy in the efficiency of identifying markers might be explained by genetic divergence of the parents used in different studies. Prakash et al. (2004) used plants from crosses of $C$. arabica and $C$. liberica, which are two genetically distant coffee species. Both Brito et al. (2010) and the present study used populations derived from the Híbrido de Timor UFV 42715. This resistant parent originated from a cross between $C$. arabica and $C$. canephora which, due to subsequent successive backcrossings with $C$. arabica, is very similar to the susceptible female parent Catuaí Amarelo UFV 2143-236 in terms of genetic diversity (Brito et al. 2010). Despite the small genetic divergence expected between the parents, they were chosen because of their importance for breeding programs. The accessions of Híbrido de Timor have been used as the main source of resistance to rust and other diseases in plant breeding (Pereira et al. 2005; Sera et al. 2008; Setotaw et al. 2010). 
Table 3 SCAR markers linked to the gene for resistance to coffee rust

\begin{tabular}{|c|c|c|c|c|c|c|}
\hline \multirow[t]{2}{*}{$\mathrm{SCAR}^{\mathrm{a}}$ marker } & \multirow[t]{2}{*}{ Primer sequence $\left(5^{\prime} \rightarrow 3^{\prime}\right)$} & \multicolumn{2}{|c|}{ Genotyping $^{\mathrm{b}}$} & \multirow{2}{*}{$\begin{array}{l}\text { Ratio } \\
\pm\end{array}$} & \multirow[t]{2}{*}{$\chi^{2 \mathrm{c}}$} & \multirow[t]{2}{*}{$p(\%)$} \\
\hline & & - & + & & & \\
\hline Gene R & - & 58 & 166 & 2.86 & 0.095 & 75.76 \\
\hline $\begin{array}{l}\text { CaRHvII } 1_{533} \\
\left(\text { ETCA-EATG }_{560}\right)\end{array}$ & $\begin{array}{l}\text { F: CAAGCCGATCATAACTTATC } \\
\text { R: TGGTGGAGAATTCCTTCAG }\end{array}$ & 54 & 170 & 3.04 & 0.095 & 75.762 \\
\hline $\begin{array}{l}\text { CaRHvII } 2_{298} \\
\left(\text { ETGT-EGGG }_{350}\right)\end{array}$ & $\begin{array}{l}\text { F: CATCGCCAGGTCATGTTC } \\
\text { R: ATCTTCAATCGGAGTAACAC }\end{array}$ & 48 & 176 & 3.14 & 1.523 & 21.700 \\
\hline $\begin{array}{l}\text { CaRHvII } 3_{459} \\
(\text { ETCA-EAGA } \\
530\end{array}$ & $\begin{array}{l}\text { F: CTGATACGGGCAATCTTATC } \\
\text { R: GTAGATCTGGAAGCTCTTC }\end{array}$ & 50 & 174 & 3.11 & 0.854 & 56.760 \\
\hline $\begin{array}{l}\text { CaRHvII } 4_{208} \\
\left(\text { ETGC-EACA }_{320}\right)\end{array}$ & $\begin{array}{l}\text { F: GATATCGCGCTTATGACAC } \\
\text { R: CTGATTGGATACTCTGACG }\end{array}$ & 54 & 170 & 3.04 & 0.095 & 75.762 \\
\hline $\begin{array}{l}\text { CaRHvII } 5_{264} \\
\left(\text { ETGT-EACA }_{480}\right)\end{array}$ & $\begin{array}{l}\text { F: CAACACTGGTAGACTCGG } \\
\text { R: ACTACTGACTTCAGGACAC }\end{array}$ & 54 & 170 & 3.04 & 0.095 & 75.762 \\
\hline $\begin{array}{l}\text { CaRHvII } 6_{437} \\
\left(\text { EGTA-ETGA }_{605}\right)\end{array}$ & $\begin{array}{l}\text { F: CTCAAAGACAATCTCAGTGG } \\
\text { R: CGTTGGTTGCCGATGATG }\end{array}$ & 52 & 172 & 3.07 & 0.380 & 53.710 \\
\hline
\end{tabular}

${ }^{\text {a }}$ SCAR designation of the locus of resistance to H. vastatrix in C. arabica race II (CaRHvII); subscripts indicate the amplicon sizes in bp and the corresponding AFLP markers are in parenthesis

${ }^{\mathrm{b}}$ The (-) sign indicates no amplification of the marker and $(+)$ indicates the presence of the amplicon in individuals from the mapping population ${ }^{\mathrm{c}}$ Chi-square test with one degree of freedom (dominant monogenic inheritance: $\left.3 \mathrm{R} \_(+) / 1 \mathrm{rr}(-)\right)$, $\alpha=0.05$ probability level

Despite the relatively low rate of polymorphism found, it was possible to identify 25 closely related markers, allowing us to obtain a saturated map focusing on regionspecific markers for the resistance gene. In a previous study,

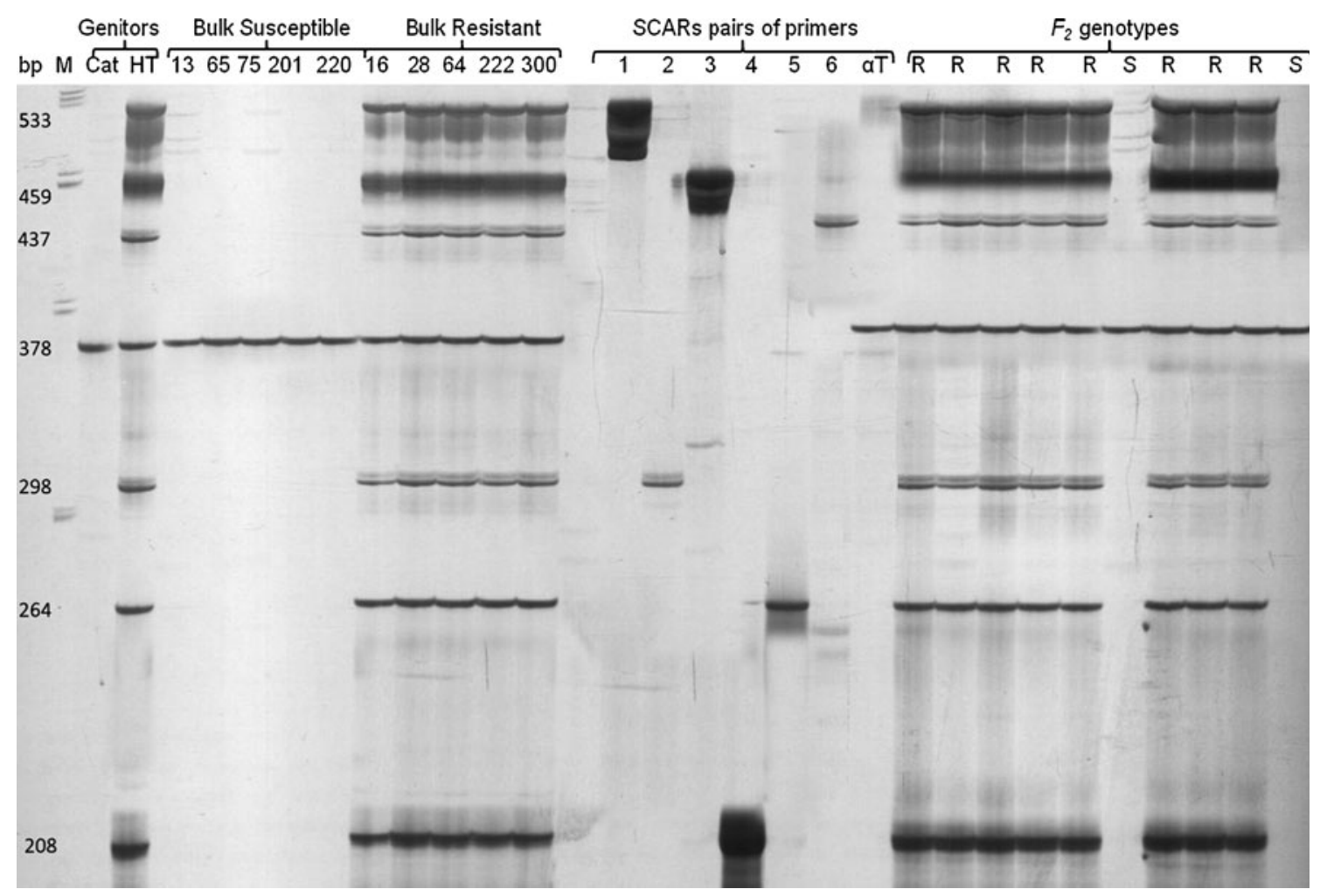

Fig. 3 Validation of the six SCAR markers closest to the R gene in a multiplex reaction. Left to right molecular weight marker (100 bp) followed by the susceptible parent, resistant parent, five individuals of the susceptible bulk, and five individuals of the resistant bulk. The following are the PCR products of specific primers for the determination of bands corresponding to the relative sizes of the amplicons (reactions with single primer pairs) and amplicons of the constitutive exon 2 of $\alpha$-tubulin (378 bp); finally, an example of segregation to the other genotypes of the UFV 421-4-n populations, which were characterized as susceptible $(S)$ and resistant $(R)$ 
Fig. 4 Genetic map of the region containing the $\mathrm{R}$ gene that confers resistance in coffee trees to $H$. vastatrix, race II. a Saturated genetic map with AFLP markers. b A highdensity genetic map with SCAR markers cosegregate with gene $\mathrm{R}$ (plotting in the "Mapmaker" format of MapDisto, 2007). Asterisk indicates significant difference for $\chi^{2}$ for a segregation of $3: 1$

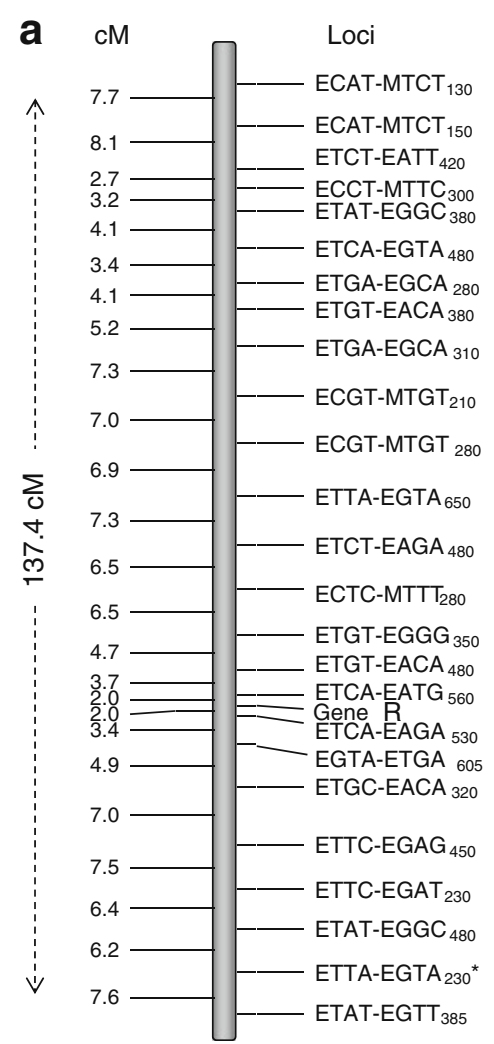

b

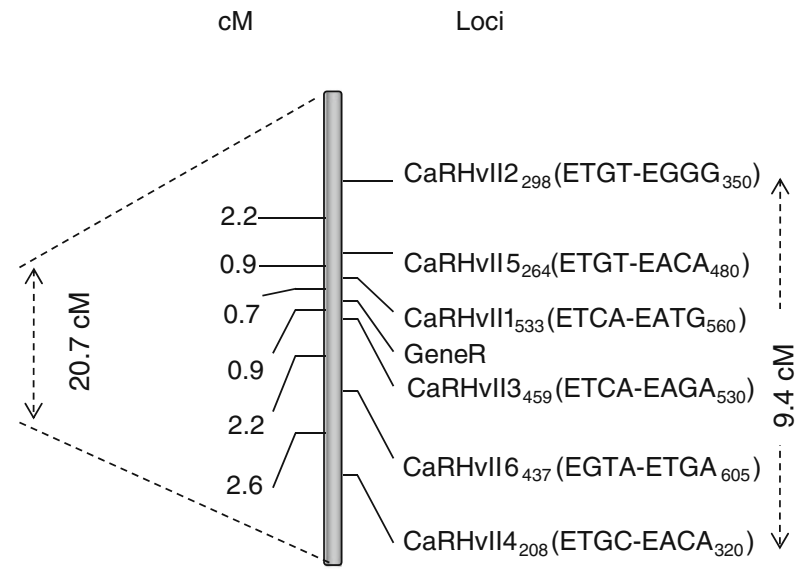

Brito et al. (2010) found three markers linked to this important resistance gene. We saturated this region and obtained a map extending to $137 \mathrm{cM}$, which allowed the positioning of three markers flanking the resistance gene at a genetic distance of less than $10 \mathrm{cM}$ on each side.

Molecular markers closely linked to the gene of interest, if transformed into specific locus markers, are of practical utility for their application in indirect selection in improvement programs (Moon and Nicholson 2007). Thus, the markers that are closest to the resistance gene were efficiently converted into SCAR markers. The SCAR is based on a single locus; it is directly amplified by PCR, easy to use, reliable, and relatively inexpensive (Hong et al. 2006).

Several studies have shown the inability to convert AFLP fragments with sizes smaller than 200 bp into SCARs (De Jong et al. 1997; Negi et al. 2000). According to Horn et al. (2003), the possibilities for the conversion of AFLP markers into specific markers is often low due to the small size of the sequences amplified by the original AFLP marker and because most of the polymorphisms obtained with AFLP originate from differences in restriction sites. However, there were no such difficulties in this study,

Table 4 Genotyping of AFLP markers located within $10 \mathrm{cM}$ of the resistance gene and their corresponding SCAR markers

\begin{tabular}{|c|c|c|c|c|c|c|c|c|}
\hline \multirow[t]{3}{*}{ SCAR marker } & \multicolumn{4}{|c|}{ AFLP (genotype) } & \multicolumn{4}{|c|}{ SCAR (genotype) } \\
\hline & \multicolumn{2}{|c|}{ Resistant } & \multicolumn{2}{|c|}{ Susceptible } & \multicolumn{2}{|c|}{ Resistant } & \multicolumn{2}{|c|}{ Susceptible } \\
\hline & $(+)$ & $(-)$ & $(-)$ & $(+)$ & $(+)$ & $(-)$ & $(-)$ & $(+)$ \\
\hline Phenotype & 166 & & 58 & & & & & \\
\hline CaRHvII $1_{533}$ (ETCA-EATG 650 ) & 159 & 7 & 51 & 7 & 166 & 0 & 54 & 4 \\
\hline CaRHvII 2298 (ETGT-EGGG 350 ) & 165 & 1 & 50 & 8 & 166 & 0 & 50 & 8 \\
\hline CaRHvII $3_{459}\left(\right.$ ETCA-EAGA $\left._{530}\right)$ & 163 & 3 & 52 & 6 & 166 & 0 & 54 & 4 \\
\hline CaRHvII $4{ }_{208}\left(\right.$ ETGT-EACA $\left._{320}\right)$ & 161 & 5 & 46 & 12 & 166 & 0 & 48 & 10 \\
\hline CaRHvII $5{ }_{264}$ (ETGT-EACA 480 ) & 158 & 8 & 49 & 9 & 166 & 0 & 52 & 6 \\
\hline CaRHvII $6_{437}$ (EGTA-ETGA 605$)$ & 160 & 6 & 53 & 5 & 165 & 1 & 53 & 5 \\
\hline
\end{tabular}

The (-) sign indicates no amplification of the marker and $(+)$ indicates the presence of the amplicon in individuals of the mapping population 
which could be explained partly by the fact that AFLP markers were converted into sequences of sizes greater than $200 \mathrm{bp}$. In addition to the efficiency of obtaining SCAR molecular markers, these were located closer to the resistance gene compared to the AFLP markers from which they originated.

The SCAR markers showed higher efficiency in genotyping the plants than the AFLPs, that is, they enabled the amplification of fragments linked to the locus in resistant plants and not in susceptible plants. For the AFLP markers, the occurrence of recombination or mutations in restriction sites can alter the DNA sequence, such that the DNA locus might consequently not be amplified (Zeng et al. 2009). However, this region would be amplified if a SCAR was used as the primer because it is not affected by the restriction site. If an AFLP had been generated by insertion or deletion of DNA fragments, the region of DNA would be still amplified. However, the size of the fragment, and hence its migration in gel electrophoresis, would be changed. Thus, it would not be possible to identify the fragment in the AFLP gel, which would be considered the absence of a fragment. As the SCAR is a specific site, fragments of different sizes would be easily detected. These facts could explain the higher genotyping efficiency of the SCAR marker. This increased efficiency of polymorphism detection enabled the reduction of genetic distances in the linkage map described in this work.

The SCAR markers obtained in this study are important tools that can be immediately used in breeding programs based on MAS due to their high efficiency in detecting resistant genotypes and their codominant nature, capable of discriminating heterozygous genotypes (Boukar et al. 2004). Thus, these markers facilitate genetic transfer of the Híbrido de Timor resistance to race II of $H$. vastatrix to cultivars susceptible to this disease by MAS. The SCAR markers found in the region of $9.45 \mathrm{cM}$, especially those flanking the gene at $0.7\left(\mathrm{CaRHvII} 1_{533}\right)$ and $0.9 \mathrm{cM}$ (CaRHvII $3_{459}$ ) cosegregate with the resistance gene and can effectively contribute to coffee-breeding programs, increasing their efficiency and reducing the selection time required to isolate genotypes containing race-specific resistance to the pathotype of race II of $H$. vastatrix.

In addition, SCAR markers may be used for future positional cloning of the resistance gene. Other studies have used this strategy for positional cloning. Xu and Korban (2002) used AFLP markers and converted them into SCARs, which reduced the genetic distances. This enabled the isolation of BAC clones and the development of a physical map including $1.1 \mathrm{Mb}$ of the $l / f$ locus for resistance genes in Malus spp. Similar studies have been performed in cowpea for resistance to Striga gesnerioides (Boukar et al. 2004), in Brassica napus for male sterility (Hong et al. 2006), in tobacco for resistance to spotted wilt virus (Moon and Nicholson 2007), and resistance to anthracnose in Phaseolus vulgaris (Beraldo et al. 2009) among others. These examples demonstrate the feasibility of the technique for such purposes.

This is the first saturated and high-density genetic map obtained from the region containing the resistance gene derived from the Híbrido de Timor. In previous studies, Prakash et al. (2004) and Mahé et al. (2008) found molecular markers linked to another gene, $S_{H} 3$, which was introgressed from the coffee species $C$. liberica. In our work, the resistance gene introgressed from the species $C$. canephora was marked using the source Híbrido de Timor. The Híbrido de Timor derivatives are major gene sources for resistance to diseases and are used in large-scale coffeebreeding programs worldwide (Pereira et al. 2005; Setotaw et al. 2010). Therefore, the results of this study are of great importance for advancing our understanding of racespecific plant-pathogen interactions and the introduction of molecular markers to facilitate the improvement of rust resistance in coffee. Moreover, the results allow for studies related to the cloning, structure, and function of racespecific genes involved in the resistance of coffee trees to H. vastatrix.

\section{References}

Alvarado GA (2005) Evolution of Hemileia vastatrix virulence in Colombia. In: Zambolim L, Zambolim EM, Várzea VMP (eds) Durable resistance to coffee leaf rust. Universidade Federal de Viçosa, Viçosa, pp 99-115

Beraldo ALA, Colombo CA, Chiorato AF, Ito MF, Carbonell SAM (2009) Aplicação de marcadores SCARs para seleção de linhagens resistentes à antracnose em feijoeiro. Bragantia 68(1):53-61

Bettencourt AJ, Noronha-Wagner M (1971) Genetic factors conditioning resistance of Coffea arabica L. to Hemileia vastatrix Berk and Br. Agron Lusit 31:285-292

Bettencourt AJ, Rodrigues CJ (1988) Principles and practice of coffee breeding for resistance to rust and other disease. In: Clarke RJ, Macrae R (eds) Coffee. Agronomy. Elsevier Applied Science, London, 4:199-234

Boukar L, Kong BB, Singh L, Murdock H, Ohm W (2004) AFLP and AFLP-derived SCAR markers associated with Striga gesnerioides resistance in cowpea. Crop Sci 44:1259-1264

Brito GG, Caixeta ET, Gallina AP, Zambolim EM, Zambolim L, Diola V, Loureiro ME (2010) Inheritance of coffee leaf rust resistance and identification of AFLP markers linked to the resistance gene. Euphytica 173:255-264

Cabral PGC, Maciel-Zambolim E, Zambolim L, Lelis TP, Capucho AS, Caixeta ET (2009) Identification of a new race of Hemileia vastatrix in Brazil. Australas Plant Dis Notes 4:129-130

Caixeta ET, Rufino RJN, Oliveira ACB et al. (2003) Caracterização da resistência genética do Híbrido de Timor UFV 427-15 à ferrugem do cafeeiro In: Simpósio de Pesquisa dos Cafés do Brasil e Workshop Internacional de Café \& Saúde, (eds): Porto Seguro. Anais. Brasília, DF : Embrapa Café. 226. 447 pp

Capucho AS, Caixeta ET, Zambolim EM, Zambolim L (2009) Herança da resistência do Híbrido de Timor UFV 443-03 à ferrugem-do-cafeeiro. Pesuisa Agrop Bras 44(3):276-282 
Cardoso RML (1986) Novas raças de Hemileia vastatrix Berk. et Berk. no Brasil, métodos de identificação, e detecção de grupos fisiológicos em cafeeiros derivados do Hibrido de Timor. Magister Scientiae. Fitopatologia, Universidade Federal de Viçosa, Viçosa-MG. 1986

Clemson M, Kelly WJ (2003) Optimizing alkaline lysis for DNA plasmid recovery. Biotechnol Appl Biochem 37:235-244

Creste S, Tulmann-Neto A, Figueira A (2001) Detection of single sequence repeat polymorphisms in denaturing polyacrilamide sequencing gels by silver staining. Plant Mol Biol Rep 4:299-306

De Jong WA, Forsyth D, Leister C, Gebhardt C, Baulcombe DC (1997) A potato hypersensitive resistance gene against potato virus $\mathrm{X}$ maps to a resistance gene cluster on chromosome 5 . Theor Appl Genet 95:246-252

Fazuoli LC, Oliveira ACB, Toma-Braguini M, Silvarolla MB (2005) Identification and use of sources of durable resistance to coffee leaf rust at the IAC. In: Zambolim L et al (eds) Durable resistance to coffee leaf rust. UFV, Viçosa, pp 137-185. doi:137

Fernandes RC, Evans HC, Barreto RW (2009) Confirmation of the ocurrence of teliospores of Hemileia vastatrix in Brazil with observations on their mode germination. Tropic Plant Pathol $34: 108-113$

Guzzo SD, Harakava R, Tsai SM (2009) Identification of coffee gene expressed during systemic acquired resistance and incompatible interaction with Hemileia vastatrix. J Phytopathol 1:1-14

Herrera JC, Alvarado G, Cortina H, Combes MC, Romero G, Lashermes P (2009) Genetic analysis of partial resistance to coffee leaf rust (Hemileia vastatrix Berk \& Br.) introgressed into the cultivated Coffea arabica L. from the diploid C. canephora species. Euphytica 167:56-67

Hong D, Wan L, Liu P, Yang G, He Q (2006) AFLP and SCAR markers linked to the suppressor gene $(R f)$ of a dominant genetic male sterility in rapeseed (Brassica napus L.). Euphytica 151:401-409

Horn R, Kusterer B, Lazarescu E, Prüfe M, Friedt W (2003) Molecular mapping of the $R f 1$ gene restoring pollen fertility in PET1-based $\mathrm{F}_{1}$ hybrids in sunflower (Helianthus annuus L.). Theor Appl Genet 106:599-606

Keb-Llanes M, González G, Chi-Manzanero B, Infante D (2002) A rapid and simple method for small-scale DNA extraction in Agavaceae and other tropical plants. Plant Mol Biol Rep 20:299a-299e

Lorieux, M (2007) MapDisto Version 1.7 beta for Excel 2007. http:// mapdisto.free.fr/. Accessed Feb 2009

Mahé L, Combes MC, Várzea VMP, Guilhaumon C, Lashermes P (2008) Development of sequence characterized DNA markers linked to leaf rust (Hemileia vastatrix) resistance in coffee (Coffea arabica). Mol Breed 21:105-113

Michelmore RW, Paran I, Kesseli RV (1991) Identification of markers linked to disease-resistance genes by bulked segregant analysis: a rapid method to detect markers in specific genomic regions by using segregating populations. Proc Natl Acad Sci U S A 88:9828-9832

Moon H, Nicholson JS (2007) AFLP and SCAR markers linked to tomato spotted wilt virus resistance in tobacco. Crop Sci 47:1887-1994

Negi MS, Devic M, Delseny M, Lakshmikumaran M (2000) Identification of AFLP fragments linked to seed coat colour in Brassica juncea and conversion to a SCAR marker for rapid selection. Theor Appl Genet 101:146-152

Pereira AA, Sakiyama NS, Zambolim L, Moura WM, MacielZambolim E, Caixeta ET (2005) Identification and use of sources of durable resistance to coffee leaf rust in the UFV/EPAMIG breeding program. In: Zambolim L, Maciel-Zambolim E, Várzea VMP (eds) Durable resistance to coffee leaf rust. UFV, Viçosa, pp 215-232

Prakash NS, Marques DV, Varzea VMP, Silva MC, Combes MC, Lashermes P (2004) Introgression molecular analysis of a leaf rust resistance gene from Coffea liberica into Coffea arabica L. Theor Appl Genet 109:1311-1317

Rodrigues CJ, Bettencourt AJ, Rijo L (1975) Races of the pathogen and resistance to coffee rust. Annu Rev Phytopathol 13:49-70

Sambrook J, Russell DW (2006) Isolation of DNA fragments from polyacrylamide gels by the crush and soak method. Cold Spring Harbor Protocols pdb.prot 2936

Sera T, Sera GH, Cardoso RML, Filho AA, Ito DS (2008) IPR 98: rust-resistant dwarf arabica coffee cultivar for dense spacing. Crop Breeding Appl Biotechnol 8:242-244

Setotaw TA, Caixeta ET, Pena GF, Maciel-Zambolim E, Pereira AA, Sakiyama NS (2010) Breeding potential and genetic diversity of "Híbrido de Timor" coffee evaluated by molecular markers. Crop Breeding Appl Biotechnol 10:289-304

Town CD, Cheung F, Maiti R, Crabtree J, Haas BJ, Wortman JR, Hine EE, Althoff R, Arbogast TS, Tallon LJ, Vigouroux M, Trick M, Bancroft I (2006) Comparative genomics of Brassica oleracea and Arabidopsis thaliana reveal gene loss, fragmentation, and dispersal after polyploidy. Plant Cell 18:1348-1359

Varzea VMP, Marques DV (2005) Population variability of Hemileia vastatrix vs coffee durable resistance. In: Zambolim L, Zambolim E, Várzea VMP (eds) Durable resistance to coffee leaf rust. UFV, Viçosa, pp 53-74

Vos P, Hogers R, Bleeker M, Reijans M, Van de Lee T, Hornes M, Frijters A, Pot J, Peleman J, Kuiper M (1995) AFLP: a new technique for DNA fingerprinting. Nucleic Acids Res 23:44074414

Xu M, Korban S (2002) AFLP-derived SCARs facilitate construction of a $1.1 \mathrm{Mb}$ sequence-ready map of a region that spans the $V f$ locus in the apple genome. Plant Mol Biol 50:803-818

Zeng F, Yi B, Tu J, Fu T (2009) Identification of AFLP and SCAR markers linked to the male fertility restorer gene of pol CMS (Brassica napus L.). Euphytica 165:363-369 